Niepełnosprawność. Dyskursy pedagogiki specjalnej

Nr 30/2018

Disability. Discourses of special education

No. 30/2018

\title{
Agnieszka Piasecka-Robak
}

Uniwersytet Przyrodniczy we Wrocławiu

\section{Wsparcie społeczne i poradnictwo dla seniorów}

Streszczenie: Niepełnosprawność często towarzyszy osobom starszym. Brak dbałości o dietę, aktywność fizyczną i zdrowy styl życia znajdują przełożenie w dysfunkcjach psychosomatycznych w późnej dorosłości. Artykuł zawiera główne tezy trzech projektów rozwojowych dla seniorów, realizowanych przez autorkę od $2010 \mathrm{r}$. Prezentuje metody pracy budujące i wzmacniające w jednostce poczucie wpływu na rzeczywistość, a równocześnie uwzględniające różne potrzeby i osobowości seniorów. Zastosowane metody: mentoring, tutoring i coaching wpisują się w ogólne trendy nauczania, a także stanowią interesującą alternatywę w promowaniu idei uczenia się przez całe życie i rozwoju osobistego seniorów, ich kompetencji i tożsamości.

Słowa kluczowe: niepełnosprawność, seniorzy, rozwój osobisty, mentoring, tutoring, coaching

\section{Social support and counseling for seniors}

Disability becomes a constant companion of an elderly person. No care for diet, physical activity and healthy lifestyle are reflected in a variety of psychosomatic dysfunctions in late adulthood. The article includes the main theses of the three development projects for seniors, implemented since 2010. It points methods of work with seniors with different needs and personalities to build their influence on reality. Applied methods: mentoring, tutoring and coaching fit into the overall teaching trends and also represent an interesting alternative in promoting the idea of lifelong learning and personal development of seniors, their competence and identity.

Keywords: disability, seniors, personal development, mentoring, tutoring, coaching

\section{Wprowadzenie}

Wraz z wiekiem granica pomiędzy starością a niepełnosprawnością jednostki może stać się coraz bardziej płynna. Dotychczas sprawny psychosomatycznie, z poczuciem wewnątrzsterowności i często samowystarczalny, senior musi zmierzyć się z nabytą niepełnosprawnością, zweryfikować własne plany i zamierzenia. Jeśli zaś od początku swego istnienia zmaga się z własną niepełnosprawnością w okresie późnej dorosłości może toczyć bezskuteczny bój o zachowanie status quo 
swoich dotychczasowych deficytów, starając się w ten sposób jak najdłużej bronić własnej autonomii.

Praca z osobą w fazie późnej dorosłości, która nabyła niepełnosprawność z uwagi na wiek i obniżającą się wraz z nim funkcjonalność organizmu, pogłębioną dodatkowo dotychczasowymi zwyczajami żywieniowymi, niekorzystnymi nawykami, zachowaniami i ogólnie pojmowanym stylem życia [por. Piasecka 2008: 85-88], staje się wielkim wyzwaniem dla pedagogów. Tym większym, iż liczba seniorów w społeczeństwie polskim gwałtownie rośnie - z danych Głównego Urzędu Statystycznego wynika, iż w Polsce mieszka 38437239 osób (w tym 19839248 kobiet i 18597991 mężczyzn). Polacy powyżej 50 roku życia stanowią w tej grupie aż 36,55\% ogółu ludności (i jest to wzrost o 1,36\% od 31.12.2011 r.). Obok osób bezrobotnych i tych, które straciły status bezrobotnych, w grupie $50+$ są przede wszystkim emeryci i renciści. Stanowią oni łącznie populację 7255600 osób, której reprezentantami w liczbie 4952700 są sami emeryci. Gdy doliczymy doń emerytów Kasy Rolniczego Ubezpieczenia Społecznego (KRUS), Ministerstwa Obrony Narodowej (MON), Ministerstwa Sprawiedliwości (MS) i Ministerstwa Spraw Wewnętrznych i Administracji (MSW, później MSWiA), sama tylko liczba emerytów osiągnie poziom 6188027 osób, czyli 16,10\% całej populacji [GUS 2015] ${ }^{1}$. Warto też dodać, iż ogólna liczba osób w wieku poprodukcyjnym w Polsce (GUS przyjmuje, iż jest to 60 lat i więcej dla kobiet, 65 lat i więcej dla mężczyzn) wynosi obecnie (dane na 31.12.2015 r.) aż 7533276 osób i zgodnie z prognozami GUS w 2035 r. może osiągnąć wysokość 9,6 mln, przekraczając tym samym $25 \%$ ogólnej liczby społeczeństwa [GUS 2016a, online: por. GUS 2014]. Powyższe liczby należy także uzupełnić informacją o ciągłym wydłużaniu się czasu trwania życia osób w wieku 60 lat, które przekłada się na następujące wartości: w 2014 r. przeciętna 60-letnia kobieta miała przed sobą jeszcze 24,3 lat życia, natomiast przeciętny mężczyzna - średnio 19,2 lat życia². Wówczas dopiero przekonamy się, iż skala zjawiska, z którym powinniśmy się mierzyć, jest bardzo duża.

Dlatego z roku na rok zwiększają się nakłady administracji publicznej na pracę z seniorami. Na popularności zyskują też programy unijne promujące ideę całożyciowego uczenia się wśród osób powyżej 50 roku życia, zaś założenia ogól-

1 Na podstawie danych Zakładu Ubezpieczeń Społecznych: w 2014 r. w Polsce emeryci i renciści stanowili ogółem 7255600 osób. W ich gronie znalazło się 4952700 osób z uprawnieniami emerytalnymi. Do tej grupy należy jednak doliczyć także dane na temat osób pobierających emerytury i renty z Kasy Rolniczego Ubezpieczenia Społecznego - 1211632 osób (w tym emeryci 951 542), Ministerstwa Obrony Narodowej - 166212 osób (w tym emeryci 111 628); Ministerstwa Sprawiedliwości 31773 osób (w tym emeryci 23 648), Ministerstwa Spraw Wewnętrznych - 205042 osób (w tym emeryci 148 509) [GUS 2015].

2 Dla porównania w 1991 r. sześćdziesięciolatkowie żyli porównywalnie o 4,5 (kobiety) i 4,1 (mężczyźni) lat mniej. Wyższy niż obecnie był wówczas także odsetek osób umierających przedwcześnie, czyli przed 60. rokiem życia. Wynosił on odpowiednio 12\% dla kobiet (w 2014 r. - 7\%) oraz $29 \%$ dla mężczyzn (w 2014 r. - 17\%) [GUS 2016b]. 
nopolskiej Długofalowej Polityki Senioralnej na lata 2014-2020 są jednym z wielu przykładów tego jak umożliwić osobom starszym aktywne starzenie się w dobrym zdrowiu oraz zwiększyć udział seniorów w życiu społecznym, zbudować i wzmocnić solidarność międzypokoleniową.

\section{Charakterystyka grupy docelowej w kontekście niepełnosprawności}

Spróbujmy przyjrzeć się nieco bliżej kondycji grupy docelowej, jaką stanowią seniorzy. Analizę warto rozpocząć od dokonanej przez nich oceny własnego stanu zdrowia i poziomu sprawności. Ponowne odwołanie się do raportów GUS sprzyja postawieniu tezy, iż polscy seniorzy źle oceniają stan swojego zdrowia ${ }^{3}$. Ich opinie potwierdzają także wyniki badań Eurostat, iż życie w zdrowiu w Polsce trwa u kobiet $77 \%$ czasu całego ich życia, zaś u mężczyzn osiąga $81 \%$. W praktyce oznacza to, iż kobiety (przeciętnie) przez pierwsze 63 lata swego życia żyją bez ograniczeń spowodowanych niepełnosprawnością, np. chorobami przewlekłymi. Mężczyźni żyją w pełnym zdrowiu już tylko pierwszych 59 lat [Eurostat 2013: $51-59]^{4}$.

Gdy jako kryterium niepełnosprawności senioralnej w Polsce przyjmiemy istnienie co najmniej jednej choroby lub dolegliwości przewlekłej z listy obligatoryjnych standardów europejskich dla osób dorosłych, okazuje się, iż dysfunkcje i choroby przewlekłe, typowe dla okresu późnej dorosłości występują u każdego $\mathrm{z}$ ankietowanych w liczbie co najmniej 3 .

Tabela 1. Liczba chorób i dolegliwości przewlekłych (średnia liczba schorzeń przypadająca na jedną osobę) jako kryterium niepełnosprawności senioralnej

\begin{tabular}{|l|c|c|c|}
\hline \multicolumn{1}{|c|}{ Grupa wiekowa } & Ogółem & Kobiety & Mężczyźni \\
\hline Ogółem & 3,6 & 3,9 & 3,2 \\
\hline 60-69 lat & 3,1 & 3,4 & 2,8 \\
\hline 70-79 lat & 4,1 & 4,4 & 3,7 \\
\hline 80 lat i więcej & 4,5 & 4,6 & 4,3 \\
\hline
\end{tabular}

Źródło: Opracowano na podstawie [GUS 2016b].

$329 \%$ osób powyżej 65. roku życia, ankietowanych przez GUS, określiło swój stan zdrowia jako „zły lub bardzo zły". Mianem "takiego sobie, ani dobrego, ani złego" nazwało go $43 \%$ ankietowanych, a tylko $28 \%$ oceniło swój stan zdrowia jako „dobry lub bardzo dobry", przy czym częściej na swój stan zdrowia skarżyły się kobiety [GUS 2016b].

4 Dalsze życie w pełnym zdrowiu u kobiet po 65. roku życia dotyczy już tylko $39 \%$ populacji kobiet w tym wieku, w przypadku mężczyzn - $46 \%$ populacji. 
Najczęstszą przyczyną problemów zdrowotnych i w konsekwencji - niepełnosprawności w kategorii wiekowej seniorów są: nadciśnienie tętnicze $(47,2 \%$ u mężczyzn oraz 56,3\% u kobiet), choroba zwyrodnieniowa stawów (47,3\% u kobiet i $29 \%$ u mężczyzn), choroba wieńcowa (28\% u kobiet i 24,8\% u mężczyzn, cukrzyca (nieco ponad 17\%, zarówno u kobiet, jak i mężczyzn) oraz choroby tarczycy (17,2\% u kobiet). Sporym problemem, wpływającym na ogólną kondycję psychofizyczną są też:

- otyłość (BMI powyżej 30) - występuje ona przeciętnie u 26\% osób w wieku 60 lat i więcej. W grupie wiekowej 60-69 lat liczba osób otyłych wzrasta do $28 \%$. Przy stopniowo obniżającej się liczbie osób przynależnych do danej kategorii wiekowej, wśród osób w wieku 70-79 lat otyłość pojawia się w 26\% przypadków, natomiast u osób w wieku 80 lat i więcej - u 19\%;

- nadwaga (BMI powyżej 25) - występuje u 44\% seniorów w wieku 60 lat i więcej. Nadwagę ma także 43\% osób w wieku 60-69 lat, 46\% w wieku 70-79 lat oraz $42 \%$ w wieku lat 80 lat i więcej.

Prawie 60\% osób powyżej 65. roku życia, badanych przez GUS, wskazało na mniejszą sprawność narządów, słabą mobilność lub ograniczenia w codziennym funkcjonowaniu. Wśród osób w wieku bardziej zaawansowanym te przypadłości narastały nawet do 80\% przypadków. Potwierdzają to także dane zebrane podczas Narodowego Spisu Powszechnego Ludności z 2011 r. - „w grupie ludności w wieku co najmniej 65 lat co trzecia osoba (ponad 1,9 mln) była niepełnosprawna - co stanowiło prawie $41 \%$ ogólnej zbiorowości osób z niepełnosprawnością" [PAP 2016, online].

\section{Rozumienie potrzeb psychicznych seniorów jako podstawa przeciwdziałania wykluczeniu społecznemu ${ }^{5}$}

Osoba o niepełnej sprawności, obok dolegliwości typowo somatycznych, może posiadać szereg niezaspokojonych potrzeb w budowaniu relacji międzyludzkich, które mogą uruchamiać w niej dodatkową niepełnosprawność społeczną. Sytuacja ta dodatkowo komplikuje się w przypadku osób starszych. Polscy seniorzy to w dużej mierze osoby z "pokolenia Baby boom”, według typologii D. Tapscotta [2010]. Reprezentanci wyżu demograficznego, coraz częściej urodzeni już po II wojnie światowej, pomiędzy 1946 r. a 1964 r., należą do

Powyższy podrozdział artykułu jest zapisem wyników blisko pięcioletniej pracy eksperckiej, konsultacyjnej i diagnostycznej autorki w projektach senioralnych: „Wzrost, rozwój i diagnoza kompetencji seniorów” (2010-2011), „Profesjonalny senior-wolontariusz w organizacji pozarządowej” (FIO 2011-2012) oraz „Rozwój kompetencji motorem zmiany” (Erasmus+, 2015-obecnie, projekt dwuletni, połączony z warsztatami rozwoju osobistego). 
generacji poddanej największej przemianie społeczno-kulturowej, świadomie uczestniczącej w transformacji politycznej. Rzeczywistość, w której funkcjonują, obecnie budzi w nich wiele obaw - gwałtowny rozwój techniczny, powstanie społeczeństwa informacyjnego i kolejne, wymagające szybkiego przyswojenia nowinki technologiczne - pogłębiają różnicę pomiędzy „niedostosowanymi seniorami" a kolejnymi pokoleniami.

W tym kontekście moment dezaktywizacji zawodowej nabywa dla nich szczególnego znaczenia - to praca stanowi o sensie ich życia. Przez pracę definiują samych siebie, od pełnionej funkcji zawodowej uzależniają poczucie własnej wartości. W ich mniemaniu posiadane pieniądze i stanowiska czynią ludzi ważnymi. Pytani o jakość własnego życia, oceniają ją przede wszystkim przez pryzmat własnych osiągnięć zawodowych. I chociaż z roku na rok spada ich zaangażowanie zawodowe, postrzegają samych siebie jako osoby lojalne i odpowiedzialne, które w swojej aktywności mogą dzielić się z innymi dotychczasowym doświadczeniem oraz mądrością życiową. Zaczyna u nich dominować nastawienie społeczne powodowane potrzebą przynależności, przejawiające się chęcią budowania nowych relacji z ludźmi oraz troską o innych. O innym niż dotychczas wymiarze tych kontaktów decydują nabywane z wiekiem nowe atuty seniorów: większa wrażliwość na nieznane dotychczas informacje oraz umiejętności dokonywania wielowymiarowej oceny człowieka i odnajdowania niepowtarzalności cech osobowości ludzkich dzięki własnej elastyczności umysłowej i emocjonalnej. Dzięki tym przymiotom mogą mniej dotkliwie odczuwać zmniejszanie się sprawności fizycznej [Piasecka 2014].

Jednakże codzienność wielu osób starszych, pozbawionych wsparcia społecznego i możliwości kompensacji potrzeb wieku senioralnego, zamiast koncentrować się na rozwiązywaniu istniejących problemów, czyni priorytetowym ich spiętrzanie i eksponowanie oraz przeświadczenie o niemożności ich przezwyciężenia. Owo niedostosowanie do rzeczywistości jest więc łączone z mniejszą niż „normalna” sprawnością psychofizyczną. Dodatkowo zaś - wzmacniane traumatycznymi wydarzeniami, jakimi są: śmierć osób bliskich, szczególnie partnera życiowego, opuszczenie domu przez dorosłe już dzieci czy zacieśniający się stopniowo krąg znajomych, przewlekle chorujących i umierających. Jak zatem pracować z seniorami, aby ich niepełna sprawność fizyczna nie była intensyfikowana faktyczną niepełnosprawnością społeczną?

\section{Praca nad doświadczaniem rzeczywistości przez osoby starsze}

Poradnictwo i wsparcie społeczne dla seniorów powinno koncentrować się na budowaniu wiary w możliwość podniesienia jakości życia tych osób [Piorunek 
2015]. Zachęta do ciągłego kształtowania własnej tożsamości, rozwoju samoakceptacji i wpływu na rzeczywistość, połączona z pomocą w obiektywnej ocenie własnej sytuacji, okiełznaniu problemów zdrowotnych i egzystencjalnych, psychologicznych i społecznych, rozwojowych i rodzinnych czy wreszcie - ekonomicznych i prawnych, może sprzyjać stworzeniu obszaru samorealizacji. Nie należy go przy tym ograniczać wyłącznie do „wymiaru eksploatacyjnego”, rozumianego jako szansa na wykorzystanie wiedzy, umiejętności i kompetencji, czerpanie z wieloletnich doświadczeń i potencjału seniora, lecz także rozszerzać o „wymiar kreacji” odkrywania i zaspokajania potrzeb seniora i skrywanych dotychczas marzeń, tak odległych od wykonywanej pracy zawodowej czy obowiązków domowych [Zych 2018]. Jak pracować z osobami starszymi, budując ich pełną sprawność społeczną i kompensując deficyty w tejże fizycznej? Jak budować interakcję rozwojową pomiędzy seniorem a osobą wspierającą? ${ }^{6}$

Efektywne spotkanie z seniorem to niewątpliwie relacja nosząca znamiona personalizacji: uwzględniająca dotychczasowe funkcjonowanie obu podmiotów dialogu (doradcy i seniora) w obszarze społecznym, prywatnym i zawodowym. Powinno ono sprowadzać się do odczytania preferowanych stylów komunikowania obojga, określenia priorytetów i osiągnięcia porozumienia w zakresie ważnych dla obojga norm i regulacji, które warunkują ich funkcjonowanie, dotychczasowych doświadczeń i zgody (lub jej braku!) na eksperymentowanie w zakresie „radzenia sobie w starości”. Takie doprecyzowanie wzajemnych oczekiwań, pomoże nam wybrać najlepszy sposób pracy z daną osobą.

Mentoring jako metoda pracy z osobą starszą służy przede wszystkim stopniowej aktywizacji seniora do poszukiwania możliwości tkwiących w nim samym i otaczającym go środowisku. Pełni przede wszystkim funkcję mobilizującą jednostkę do dalszego działania i dyscyplinującą jej postępowanie w celu uwolnienia się od poczucia bezradności i braku sensu dalszego życia. Wspiera seniora w ponownym określeniu swojej pozycji, budzi w nim gotowość do wejścia w nowe role społeczne i uświadamia zachodzącą w nim zmianę. Osoba starsza, wchodząca w nowe relacje, buduje je bowiem w odmienny niż dotychczas sposób - jest nastawiona na utrzymywanie stosunków z innymi ludźmi, realizuje siebie w procesie

\footnotetext{
6 W definicji terminu „poradnictwo gerontologiczne”, opracowanego wraz z dr Małgorzatą Malec-Rawinski na potrzeby „Encyklopedii starzenia się i starości”, pod red. prof. A.A. Zycha, opisałam podstawy budowania relacji doradca-senior jako relacji praktycznej [Zych 2018]. Podkreślenie wymiaru empirycznego w poradnictwie społecznym jest według mnie powrotem do humanistycznych założeń, jakie stawiała przed sobą pedagogika u zarania swych dziejów - do aktu niesienia pomocy Drugiemu Człowiekowi i wspierania Go, nawet jeśli nie są one poparte wieloetapową refleksją metodologiczną czy rozważaniami teoretycznymi dotyczącymi uzasadnienia stosowanych technik, a "jedynie" doświadczeniem, intuicją i empatią osoby niosącej pomoc. Piasecka-Robak A., Malec-Rawinski M., Poradnictwo gerontologiczne (hasło encyklopedyczne) [w:] Encyklopedia starości, starzenia się i niepetnosprawności, red. A.A. Zych, t. 3, Wydawnictwo Naukowe "Śląsk", Katowice, s. 73-77.
} 
tworzenia i dawania. Czuje się potrzebna i ważna, o ile jest niezbędna innym i ludzie chcą korzystać z jej „właściwości ukształtowanych przez życie” [Harwas-Napierała 2015: 110]. W ten sposób, troszcząc się o innych, unika tzw. wtórnej egocentryzacji [Harwas-Napierała 2012; Straś-Romanowska 2000: 263-292; Brzezinska 2002: 11-22].

Mentor uświadamia seniorowi wielość obszarów dalszej aktywności społecznej, np. spędzania czasu wolnego, kieruje nim w procesie odkrywania jego możliwości i ograniczeń, a w konsekwencji - buduje gotowość do przezwyciężania słabości i wykorzystania własnego potencjału [por. Sidor-Rządkowska 2014]. Mentoring jest skutecznym sposobem oddziaływania na osobę „zagubioną w swojej niepełnosprawności" - mentor obliguje bowiem seniora do pracy nad identyfikacją priorytetów życiowych, dopytuje o nie, aby pomóc seniorowi $\mathrm{w}$ ustaleniu realnych celów do osiągnięcia. Prezentuje tzw. dobre wzorce i rozwiązania, mobilizując $\mathrm{w}$ tej sposób seniora do zwiększonej samoświadomości i autorefleksyjności. Jednak jego „skuteczność” kończy się wraz ze wzrostem obu tych umiejętności. Kiedy osoba starsza uświadamia sobie, jak wielki ma wpływ na własne życie i postanawia aktywnie kreować jego przebieg, relacja mistrz-uczeń, wytyczająca wzajemne reguły współpracy, przestaje być niej atrakcyjna. Senior zaczyna dążyć do przejęcia odpowiedzialności za dalsze wytyczanie kierunków własnego rozwoju. Traci na znaczeniu podstawowy cel tejże - wytyczanie kierunku rozwoju seniora. Dyrektywny sposób pracy z seniorem przestaje być atrakcyjny dla niego samego. Dlatego właśnie mentoring bywa szczególnie skuteczny w dwóch przypadkach: na początku pracy z osobą starszą, o nabytej niepełnosprawności, która nie potrafi odnaleźć się w nowej dla siebie rzeczywistości lub w pracy z osobami konformistycznymi, które obawiają się podejmowania odpowiedzialności za własne działania i muszą rozwinąć w sobie kompetencje społeczne. Wówczas taki mistrz nie tylko wytycza ścieżki rozwoju seniora, ale też pełni rolę motywującą $\mathrm{w}$ tymże, weryfikując postępy pracy osoby starszej i pomagając $\mathrm{mu} \mathrm{w} \mathrm{"wyprostowaniu”} \mathrm{własnych} \mathrm{zakrętów} \mathrm{życiowych.} \mathrm{Takim} \mathrm{mentorem} \mathrm{może}$ być trener pracy, pracownik socjalny lub specjalista w zakresie edukacji i psychologii osób dorosłych, ze szczególnym uwzględnieniem gerontologii [por. Szarota 2010]. Jego rolą jest przede ustalenie reguł, które senior zintegruje i wedle których będzie budował własną odwagę do samodzielnego życia. To mentor ponosi odpowiedzialność za efektywność tejże relacji. Sam stanowi wzorzec postępowania dla swojego „ucznia”, i przedstawia mu inne wzorce życia, które są mu znane, tworząc w ten sposób wzajemną zależność w diadzie. Mentor jest tym, który ma doświadczenie i chce się nim dzielić z uczniem. Dzieli się także receptą na udane życie dla tegoż seniora - udane w mniemaniu mentora, rzecz jasna. W nieco przerysowanej formie - jest niczym behawiorystyczny Skinner budujący odruchy warunkowe u seniora lub psychoanalityczny Freud, wiedzący lepiej, co jest dobre dla jego „pacjenta”. 
Pojawia się tutaj jednak pytanie zasadnicze - na ile człowiek świadomie budujący swoją egzystencję przez długie lata dorosłości jest w stanie zaakceptować na dłużej obecność „eksperta od cudzego życia”. Na etapie początkowego zagubienia seniora $\mathrm{w}$ określaniu samego siebie i w relacji do innych, taka diada zakładająca wsparcie specjalisty czy podążanie za mistrzem może być dla jednostki świetną trampoliną, od której odbije się odważnie, startując ku nowej rzeczywistości. Jednak wraz ze wzrostem akceptacji dla własnych ograniczeń senior łatwiej dostosowuje się do zmian zachodzących w otaczającym go środowisku. Oczekuje także innych niż dotychczas form wsparcia i pomocy, odmiennych od „podążania za mistrzem".

Zyskująca samoświadomość osoba starsza, obok wad obniżającej się sprawności psychosomatycznej, potrafiąca dostrzec także zalety innego niż dotychczas sposobu budowania relacji społecznych i oczekiwań wobec tychże, zaczyna poszukiwać stymulacji na innym poziomie interpersonalnym. Zaczyna głośno artykułować własne oczekiwania odnośnie wchodzenia w nowe role społeczne. „Mogłabym poczytać dzieciom książkę, zrobić ładny kwiat z bibuły, zaśpiewać kołysankę", deklarowała w ankiecie jedna z seniorek biorących udział w projekcie „Profesjonalny senior-wolontariusz w organizacji pozarządowej”, po etapie aktywizacji i określenia własnych możliwości. Mówiąc o wychodzeniu poza swoje dotychczasowe bezpieczne pozycje seniorzy, uczestniczący $\mathrm{w}$ realizowanych przeze mnie projektach, mówili przede wszystkim o potrzebie "osiągnięcia czegoś wartościowego (...) i poczucia, że jestem niezależny", "podjęcia różnych typów odpowiedzialności”, otrzymywaniu szacunku i wsparcia oraz „możliwości rozwijania przyjaźni" i „korzystania ze (...) specjalnych umiejętności [seniora przyp. aut.], dotychczas niewykorzystanych" oraz „wykorzystania własnej kreatywności". Oczekiwania te powtarzały się wielokrotnie, mimo niezwykle różnych poziomów sprawności badanych. Badani jasno wskazywali na swoje ograniczenia psychofizyczne, równocześnie odkrywając inne obszary własnej egzystencji, w których czują się dobrze i sposób, w jaki chcą budować nowe relacje. Niejednokrotnie pojawiła się także deklaracja "poczucia własnego wkładu w realizowane projekty" - to sformułowanie najlepiej doprecyzowuje dążenia seniorów w budowaniu swojego dalszego życia. Takie świadomość wkładu własnego może być bowiem świetnie budowana $\mathrm{w}$ trakcie pracy tutoringowej.

Tutoring jako metoda zakłada stworzenie relacji bardzo mocno spersonalizowanej, nastawionej na realizację rozwoju osobistego seniora poprzez stawianie przed nim ciekawych zadań, umożliwiających niezależność działania. Tutoring koncentruje się na dialogu oraz budowaniu relacji wzajemnego szacunku i współodpowiedzialności za proces [por. Czekierda, Fingas, Szala 2015]. Sięga po założenia psychologii poznawczej - ten model wsparcia zakłada wzajemną ciekawość poznawczą obu podmiotów diady. Senior jest wspierany przez tutora - partnera, 
który przez wspólną rozmowę budzi wzajemne zainteresowanie. Dialog obojga jest nie tylko dochodzeniem do porozumienia i wypracowaniem wspólnych rozwiązań - jest przede wszystkim okazją do poznania siebie, odkrywania nowych znaczeń i (re)negocjowania starych. Udzielane wsparcie jest jednocześnie konsultacją, za którą oboje ponoszą odpowiedzialność. Taki sposób pomocy świadczonej osobie starszej buduje w podmiotach tejże diady wzajemny szacunek. Zaangażowany w proces tutor stwarza równie zaangażowanemu we własny rozwój seniorowi możliwości do autorefleksji, samodzielnego zgłaszania i realizacji pomysłów, podjęcie inicjatywy. Rolą tutora jest dbałość o proces uczenia się osoby starszej i wyciągania przez nią wniosków nawet $\mathrm{z}$ nieudanych przedsięwzięć. Ma on zachęcać do sprawdzania siebie w różnych kontekstach życia i relacjach, równocześnie wyrażając gotowość na przyjmowanie informacji zwrotnej na temat wyników seniora w pracy nad sobą i poziomu osiąganej satysfakcji. W ten sposób wzmacnia budowę tożsamości i autorytetu osoby starszej. Tutor daje seniorowi poczucie bezpieczeństwa w "próbowaniu siebie” na różnych płaszczyznach społecznych oraz wsparcie, na które ten oczekuje w danym momencie i o które poprosi tutora. Tutor buduje $\mathrm{w}$ seniorze wrażliwość na nowe informacje i taktyki działania, stwarza mu okazje do zwiększenia własnej integracji wewnętrznej i harmonii. Odwaga postępowania jest jednak zawsze domeną seniora. Motywowany przez tutora, sam decyduje o kształcie swojego życia [Harwas-Napierała 2015: 113; por. Neugarten 1968]. Przykładem relacji tutorskiej może być asystent osoby starszej.

Dalszy rozwój osobisty osoby starszej, szczególnie zdobycie i rozwinięcie przez nią kompetencji przywódczych oraz postawy gotowości do ich wdrażania, sprawiają, iż zarówno mentor, jak i tutor przestają pełnić funkcję stymulującą. Pozyskanie postawy gotowości do wdrażania nowych rozwiązań, większa odwaga do samodzielnego kierowania swoim losem i wyznaczania ważnych celów życiowych przez świadomego seniora to wyzwanie dla coacha.

Coaching, bazując na założeniach psychologii humanistycznej, pozwala na budowanie relacji liberalnej pomiędzy coachem a seniorem (coachee). Ten szczególny układ pomiędzy wspierającym i wspieranym zakłada olbrzymi potencjał osoby starszej oraz jej gotowość do samostanowienia. Senior uczestniczący w coachingu to senior świadomy większości swoich ograniczeń i wynikających z tego utrudnień egzystencjalnych. Zna swoje mocne i słabe strony. Potrafi obiektywnie określić rzeczywistość, w której się znajduje, a także - w oparciu o szanse i zagrożenia tkwiące w nim samym oraz środowisku - nakreślić alternatywy rozwiązań dla swojej sytuacji. Do tego dochodzi jeszcze wola realizacji wybranego działania przez jednostkę. Coach jest tym, który zadając pytania, skłania seniora do refleksji nad systemem wartości, priorytetami i realnymi możliwościami osiągnięcia własnego celu rozwojowego. Tym samym zachęca go do projektowania własnej 
rzeczywistości, niejako na zasadzie samospełniającej się przepowiedni. Coach wspiera osobę starszą w poszukiwaniu powiązań i przynależności pomiędzy nią a środowiskiem społecznym, zachęca do odnalezienia podobieństw celów i dążeń spójnych z dążeniami ogółu. Wspiera w redefiniowaniu i rozwoju własnej tożsamości. Pośrednio też - poprzez zmotywowanie seniora do odnalezienia własnej „pełnowartościowości” i odczucia „pełnosprawności w dodawaniu życia do lat” przyczynia się do zmiany postrzegania społecznego tejże osoby: jako bardziej świadomej i samodzielnej, ukierunkowanej na osiągnięcie celu. Tym samym wzrasta jej status społeczny [Piasecka 2015: 38-50].

Skoro w coachingu podmiotem wsparcia jest senior, to on sam ponosi odpowiedzialność za proces pomagania. To on wytycza warunki, na jakich jest wspierany oraz reguły wzajemnej współpracy. Coach natomiast czuwa nad osiągnięciem celów istotnych dla seniora, dba o ich dookreślenie oraz dopytuje o jakość relacji budowanych pomiędzy seniorem a środowiskiem społecznym, w którym funkcjonuje osoba starsza. Mobilizuje seniora do walki o swoją przyszłość i czerpanie satysfakcji z życia, z równoczesną świadomością ograniczeń, jakie niesie ze sobą wiek osoby coachowanej i poziom jej sprawności psychofizycznej. Aktywuje także inny istotny element składający się na egzystencję osoby starszej - stawia przed seniorem wyzwanie polegające na konieczności odniesienia się do zasobów wewnętrznych i tych, które stanowią jego bliskie otoczenie społeczno-kulturowe, w celu świadomego budowania relacji opartych na wzajemnym wsparciu społecznym. Wreszcie - po rozpatrzeniu wszelkich dostępnych możliwości, obliguje jednostkę do oceny skuteczności podejmowanych dotychczas działań. Coach dopytuje także o wolę podjęcia działania przez osobę starszą - sama decyzja wyjścia poza swoją niepełną sprawność należy zatem do podmiotu wsparcia. To on wyznacza poziom swojej gotowości i czas rozpoczęcia jakiejkolwiek zmiany.

W tabeli 2 przedstawiłam wytyczne dotyczące zastosowania mentoringu, tutoringu i coachingu w pracy z osobami starszymi

Wnioskując z tabeli 2 - zastosowanie mentoringu we wspieraniu osób w okresie późnej dorosłości, choć może być niezwykle efektywne na początku pracy z seniorami zagubionymi, odczuwającymi wykluczenie, a nawet bezradność, poszukującymi informacji na temat możliwości zmiany swojej sytuacji, może też skrzywić nam postrzeganie osób starszych, utrudnić dostrzeżenie, iż mimo mniejszej sprawności fizycznej, legitymują się oni często wyższym poziomem wiedzy i umiejętności, a także - większym doświadczeniem życiowym i zawodowym niż potencjalny mentor. Wdrożenie tutoringu powinno odbywać się dopiero w momencie wyrażenia przez seniora gotowości do dalszego rozwoju. Wprowadzane stopniowo, ma sprzyjać przede wszystkim budowaniu samodzielności osoby

7 Wytyczne są rozwiązaniami wypracowanymi w toku trzech projektów badawczych. Ich realizację poprzedziła jakościowa analiza treści na temat mentoringu, tutoringu i coachingu. 
starszej i refleksyjności. Z kolei zastosowanie coachingu - na zasadzie przeciwwagi dla podejścia mentorskiego - może zupełnie nie sprawdzać się $\mathrm{w}$ przypadku osób wykluczonych, które utraciły wiarę w możliwość samostanowienia. Zmotywuje jednak z pewnością osoby ze skłonnością do autorefleksji, znające swoje potrzeby i świadome tego, co daje im prawdziwą satysfakcję.

Tabela 2. Wdrażanie wsparcia i pomocy poprzez mentoring, tutoring i coaching

\begin{tabular}{|c|c|c|}
\hline Mentoring & Tutoring & Coaching \\
\hline $\begin{array}{l}\text { Podstawa naukowa: } \\
\text { - psychologia behawiorystycz- } \\
\text { na i elementy psychoanalizy; } \\
\text { - paradygmat pozytywistyczny }\end{array}$ & $\begin{array}{l}\text { Podstawa naukowa: } \\
\text { - psychologia poznawcza; } \\
\text { - paradygmat emancypacyj- } \\
\text { no-krytyczny }\end{array}$ & $\begin{array}{l}\text { Podstawa naukowa: } \\
\text { - psychologia humanistyczna; } \\
\text { - paradygmat interpretatywny } \\
\text { (rozumiejący) }\end{array}$ \\
\hline $\begin{array}{l}\text { Sposób traktowania osoby } \\
\text { wspieranej: dyrektywny, } \\
\text { ukierunkowujący }\end{array}$ & $\begin{array}{l}\text { Sposób traktowania osoby } \\
\text { wspieranej: dialogowy, konsul- } \\
\text { tacyjny }\end{array}$ & $\begin{array}{l}\text { Sposób traktowania osoby } \\
\text { wspieranej: liberalny, facyli- } \\
\text { tujący }\end{array}$ \\
\hline $\begin{array}{l}\text { Odpowiedzialność: po stronie } \\
\text { mentora }\end{array}$ & $\begin{array}{l}\text { Odpowiedzialność: po stronie } \\
\text { osoby wspieranej i tutora }\end{array}$ & $\begin{array}{l}\text { Odpowiedzialność: po stronie } \\
\text { osoby wspieranej (coachee) }\end{array}$ \\
\hline $\begin{array}{l}\text { Moment wdrożenia metody: } \\
\text { początek aktywizacji osoby } \\
\text { niepełnosprawnej lub zagrożo- } \\
\text { nej wykluczeniem z tzw. wy- } \\
\text { uczoną bezradnością }\end{array}$ & $\begin{array}{l}\text { Moment wdrożenia metody: } \\
\text { osoba znająca swoje mocne i } \\
\text { słabe strony, wyrażająca chęć } \\
\text { działania }\end{array}$ & $\begin{array}{l}\text { Moment wdrożenia metody: } \\
\text { osoba zorientowana na działa- } \\
\text { nie, zmotywowana do ustana- } \\
\text { wiania i osiągania ważnych dla } \\
\text { siebie celów rozwojowych }\end{array}$ \\
\hline $\begin{array}{l}\text { Typ osiągniętej zmiany: zmiana } \\
\text { ilościowa (ukierunkowana } \\
\text { aktywizacja społeczna, pod } \\
\text { przewodnictwem mistrza, } \\
\text { uczącego reguł integracji) }\end{array}$ & $\begin{array}{l}\text { Typ osiągniętej zmiany: zmiana } \\
\text { ilościowa (gotowość do rozwo- } \\
\text { ju stymulowana w dialogu } \\
\text { z osobą wspierającą) i jakościo- } \\
\text { wa (gotowość do samodziel- } \\
\text { nego kształtowania ścieżki } \\
\text { rozwoju i deklarowania włas- } \\
\text { nego stanowiska odnośnie } \\
\text { reguł edukacji włączającej) }\end{array}$ & $\begin{array}{l}\text { Typ osiągniętej zmiany: zmiana } \\
\text { jakościowa (samodzielny rozwój } \\
\text { osoby coachowanej przy nie- } \\
\text { wielkim wsparciu coacha, dąże- } \\
\text { nie do samorealizacji, świadoma } \\
\text { inkluzja społeczna, sprzyjająca } \\
\text { poszukiwaniu własnej tożsa- } \\
\text { mości) }\end{array}$ \\
\hline
\end{tabular}

Źródło: Opracowanie własne na podstawie [Kozielecki 1997; Malewski 1998; Wojtasik 1997].

Niezależnie od tych trzech sposobów wsparcia, dominujących w obecnej literaturze przedmiotu i praktyce psychopedagogicznej, traktowanych coraz częściej jako formy wręcz systemowe, z racji sformalizowania ich zastosowania w placówkach edukacyjnych [por. Wojtasik 2012; Wojtasik 1997], wsparcie i pomoc moga być udzielane seniorom w sposób nieformalny, nieoficjalny. Tak też dzieje się najczęściej - nie każda osoba starsza decyduje się na skorzystanie z pomocy specjalisty, np. certyfikowanego coacha, tutora czy mentora. Niezwykle często osobą wspierającą staje się dla niej przypadkowa osoba, która buduje z nią relacje międzyludzkie, na zasadzie intencjonalności (inspirując seniora do tworzenia lub modyfikacji własnej biografii poprzez popularyzację tzw. dobrych praktyk, które stały się udziałem tegoż przypadkowego doradcy) lub w sposób całkowicie nieza- 
mierzony. Takie wsparcie cechuje niezwykle wysoki poziom wiarygodności, wzajemna inspiracja do doświadczania świata i dążenie do naśladownictwa [por. Krumboltz, Levin 2014]. Przypadkowość, cechująca takie wsparcie, stanowi swoistą zachętę do "wsłuchiwania się w swój głos wewnętrzny", eksperymentowania i realizacji dotychczas nieosiągalnych marzeń, nawet kosztem popełniania błędów - traktowanych tutaj jako źródło nauki [Czerniawska 2007].

Niezależnie od zastosowanych form wsparcia, jak też - poziomu gotowości osoby starszej do przyjęcia pomocy, ich cel pozostaje ten sam. Jest nim pomoc $\mathrm{w}$ harmonijnym rozwoju seniora oraz zmniejszenie ryzyka wystąpienia poczucia braku sensu życia i własnej bezwartościowości. Jeśli osobom wspierającym naprawdę zależy na dobrostanie psychosomatycznym osoby starszej o ograniczonej sprawności, znajdą oni możliwość, aby stworzyć szanse na zaspokojenie potrzeb seniorów. Niezależnie od tego, czy zastosują mentoring, tutoring, coaching czy wsparcie nieformalne powinni jednak mieć zawsze na uwadze fakt, iż tylko wymagające otoczenie społeczne, wiążące konkretne nadzieje z osobą starszą, oczekujące od niej autonomii i niezależności, decyzyjności i samodzielności intelektualnej, umożliwi seniorowi zachowanie sprawności nawet w podeszłym wieku. Paradoksalnie: każda strata, nawet ta która wiąże się ze stratą sprawności psychosomatycznej, może dać człowiekowi szansę na weryfikację dotychczasowych postaw i filozofii życia, a w konsekwencji - stanowić nową szansę dla refleksyjnego rozwoju i zmiany postępowania, spojrzenia na świat z perspektywy niedostrzeganej przez osoby doświadczające dobrostanu psychofizycznego [Piasecka 2014; Brzezińska 2004].

\section{Bibliografia}

Anderson D., Anderson M. (2005), Coaching That Counts. Harnessing the Power of Leadership Coaching to Deliver Strategic Value, Elsevier Butterworth-Heinemann, Oxford.

Brzezińska A. (2002), Dorosłość - szanse i zagrożenia dla rozwoju, [w:] Szanse i zagrożenia rozwoju w okresie dorosłości, red. A. Brzezińska, K. Appelt, J. Wojciechowska (red.), Wydawnictwo Fundacji „Humaniora”, Poznań, s. 11-22.

Czekierda P., Fingas B., Szala M. (red.) (2015), Tutoring. Teoria, praktyka, studia przypadków, Oficyna a Wolters Kluwer business, Warszawa.

Czerniawska O. (2007), Szkice z andragogiki i gerontologii, Wydawnictwo WSHE, Łódź.

Eurostat (2013), Key figures on Europe 2013 digest of the online Eurostat yearbook, Publications Office of the European Union, European Commission - Pocketbooks, Luxembourg, s. 51-59.

GUS 2014: Główny Urząd Statystyczny (listopad 2014), Sytuacja demograficzna osób starszych i konsekwencje starzenia się ludności Polski w świetle prognozy na lata 2014-2050, Wydawnictwo Zakład Wydawnictw Statystycznych, Warszawa.

GUS 2015: Główny Urząd Statystyczny (2015), Emerytury i renty w 2014, Wyd. Zakład Wydawnictw Statystycznych, Warszawa. 
GUS 2016a: Główny Urząd Statystyczny (2016), Ludność wedtug ptci, wieku, województw i powiatów. Polska stan w dniu 31 XII 2015, http://demografia.stat.gov.pl/bazademografia/Downloader.aspx?file=pl_lud_2015_00_05.zip\&sys=lud [24.05.2016].

GUS 2016b: Główny Urząd Statystyczny (2016), Ludność w wieku 60 lat i więcej. Notatka przygotowana na posiedzenie Sejmowej Komisji Polityki Senioralnej dotyczace "Informacji Ministra Zdrowia na temat wplywu zmian demograficznych i starzenia się społeczeństwa na organizacje systemu ochrony zdrowia i Narodowy Program Zdrowia" (w dniu 19.02.2016 r.), Zakład Wydawnictw Statystycznych, Warszawa.

Harwas-Napierała B. (2012), Dorosłość jako spełnienie: drogi i zagrożenia rozwoju człowieka w okresie dorostości, Wydawnictwo Libron, Kraków.

Kozielecki, J. (1997), Koncepcje psychologiczne człowieka, wyd. 7, Wydawnictwo Akademickie ŻAK, Warszawa.

Krumboltz J.D., Levin A.S. (2014), Szczęście to nie przypadek. Do odważnych świat należy! Nie bój się działać, przeł. P. Bucki, wyd. 2, Funky Books Grupa Wydawnicza GWP, Gdańsk.

Malewski M. (1998), Teorie andragogiczne. Metodologia teoretyczności dyscypliny naukowej, Wydawnictwo UWr., Wrocław.

Neugarten B.L. (red.) (1968), Middle age and aging: A reader in social psychology, University of Chicago Press, Chicago.

PAP (2016), GUS: seniorzy w Polsce źle oceniaja swój stan zdrowia, http://www.rynekseniora.pl/zdrowie/116/gus_seniorzy_w_polsce_zle_oceniaja_swoj_stan_zdrowia,375.html [24.05.2016].

Piasecka A. (2008), Komunikowanie wartości zdrowia w polskich kampaniach społecznych-wymiar edukacyjny, Wydawnictwo Adam Marszałek, Torun.

Piasecka A. (2014), Poradnictwo wolontariackie, Wydawnictwo Adam Marszałek, Toruń.

Piasecka A. (2015), Kulturowe aspekty wdrażania coachingu w pracy z niepetnosprawnymi [w:] Niepetnosprawność. Dyskursy pedagogiki specjalnej nr 18, s. 38-50.

Piorunek M. (red.) (2011), Poradnictwo. Kolejne przybliżenia, Wydawnictwo Adam Marszałek, Toruń.

Piorunek M. (red.) (2015), Dymensje poradnictwa i wsparcia społecznego w perspektywie interdyscyplinarnej, Wydawnictwo Uniwersytetu im. Adama Mickiewicza w Poznaniu, Poznań.

Sidor-Rządkowska M. (red.) (2014), Mentoring. Teoria, praktyka, studia przypadków, Oficyna a Wolters Kluwer business, Warszawa.

Straś-Romanowska M. (2000), Późna dorostość [w:] Psychologia rozwoju człowieka, t. 2: Charakterystyka okresów życia człowieka, red. B. Harwas-Napierała, J. Trempała, Wydawnictwo Naukowe PWN, Warszawa, s. 263-292.

Szarota Z. (2010), Starzenie się i starość w wymiarze instytucjonalnego wsparcia, Wyd. Uniwersytetu Pedagogicznego, Kraków.

Tapscott D. (2010), Cyfrowa dorosłość. Jak pokolenie sieci zmienia nasz świat, tłum. P. Cypryański, Wydawnictwa Akademickie i Profesjonalne, Warszawa.

Wojtasik B. (1997), Warsztat doradcy zawodu. Aspekty pedagogiczno-psychologiczne, Wydawnictwo Szkolne PWN, Warszawa.

Wojtasik B. (2012), Refleksje na temat stanu polskiego poradnictwa, "Studia Poradoznawcze”, nr 1, s. 35-47.

Zych A.A. (red.) (2015), Encyklopedia starzenia się i starości, Wydawnictwo Śląsk, Katowice. 